\title{
Critical Normativity
}

\section{Citation}

Joseph W. Singer, Critical Normativity, 20 Law and Critique 27 (2009).

\section{Published Version}

doi:10.1007/s10978-008-9038-6

\section{Permanent link}

http://nrs.harvard.edu/urn-3:HUL.InstRepos:3293010

\section{Terms of Use}

This article was downloaded from Harvard University's DASH repository, and is made available under the terms and conditions applicable to Other Posted Material, as set forth at http:// nrs.harvard.edu/urn-3:HUL.InstRepos:dash.current.terms-of-use\#LAA

\section{Share Your Story}

The Harvard community has made this article openly available.

Please share how this access benefits you. Submit a story.

\section{Accessibility}




\title{
CRITICAL NORMATIVITY
}

\author{
Joseph William Singer*
}

\section{ABSTRACT}

Skeptics argue that statements about right and wrong are merely expressions of preferences. They are mistaken; values are not the same as mere preferences. When we assert preferences that affect others, we justify our actions by giving reasons that we believe others should accept. When we evaluate those reasons, we typically reject certain preferences as illegitimate. Values are different from preferences because they entail demands we feel entitled to make of each other, after critical reflection. But this does not require us to become moral realists who base value judgments on the existence of moral facts. Critical normativity adopts the paradoxical stance that value judgments are based on human will but that they can be right or wrong. Human beings cannot live without strong normative claims but we are obligated to be careful about them. This article illustrates this stance by telling three parables of justice.

The neighbor to love as yourself is down the street.

$\sim$ Marie Brottes

Weapons of the Spirit (1989)

It was the human thing to do.

$\sim$ Roger Darcissac

Weapons of the Spirit (1989)

You know, I think I'm fine with okay.

$\sim$ Zach Helm

Stranger than Fiction (2006)

Is there any difference between a preference and a value? When we say that some course of conduct is wrong, do we have any basis for backing up our claim? Some skeptics insist that statements about right and wrong are merely

\footnotetext{
* Bussey Professor of Law. Thanks and affection go to Martha Minow, Sharon Dolovitch, Avi Soifer, Johan van der Walt. I want to give special thanks to Mira Singer, whose insights are reflected in this article.
} 
expressions of preferences - strong preferences, perhaps, but preferences nonetheless. To the contrary, I want to argue that values are not the same as mere preferences. It is true that one cannot prove that something is morally wrong the way one can use scientific evidence to prove that the world is not flat. But it does not follow that values are best interpreted as strong preferences or as expressions of emotional reactions like disgust. Nor is the view that values are mere preferences acceptable as a foundation for a society founded on the rule of law and the promotion of equal concern and respect for persons in a free and democratic society. When we say, for example, that torture is wrong, we are not merely expressing a preference. But what, indeed, are we saying? What backs up our assertion that torture is wrong?

This question, unfortunately, is a live one in the United States. That is not something I ever would have anticipated would be the case when I was a child. I took some things for granted and the wrongness of torture was one of them. The twin tragedies of 9/11 and the presidency of George Bush the second changed all that. While it is still politically impossible in the U.S. to say that torture is legitimate, it has become possible to argue that the definition of torture should be, shall we say, tightly construed so as to encompass only the most medieval of forms, thereby conveniently allowing a number of other forms that ordinary people would consider to be beyond the pale. It has also become possible to hear arguments that relegate all power to the President to determine what constitutes torture, free of checks and balances from either the Congress or the courts - a freedom reminiscent of Thomas Hobbes's proposal to vest absolute authority in a monarch, a system of government that one would have thought was the opposite of a democracy.

Still the problem remains. When we say that torture is wrong, are we saying anything other than "I prefer that you stop torturing that man"? I believe the answer is yes. But explaining why the answer is yes turns out to be a tricky business. After all, critical thinking requires us to analyze statements of both fact and value to determine their basis, their internal consistency, and their authority. When we do this - that is, when we think carefully and critically about the basis of claims of morality and justice - we find that at some point, we are left with nothing but a claim. Now claims are different from preferences because they constitute moral demands directed to others. The claim that we should not engage in torture is not merely a statement of preference. It is not to say that you prefer to engage in torture and I prefer to avoid it, the way one might talk about our preferences for chocolate or vanilla ice cream. A claim is not even a preference about preferences; rather, it is a demand directed to others as well as to ourselves about the appropriate contours of conduct for human beings in society. It is an assertion that expresses an evaluation about preferences, but it goes beyond that to enjoin human beings to order their affairs in certain ways and to do so for certain reasons. 
But, as we all know, critical thinking can undermine claims. Evaluative assertions must be defended in some way and they must be reconciled with potentially conflicting claims. There are thus two basic problems with evaluative assertions: first, establishing their basis or foundation, and second, reconciling conflicting claims. Critical thinking undermines both these tasks. When we attempt to establish the foundation for a claim, we give reasons to back up our moral demand. We may say, for example, that torture is wrong because it fails to treat persons with dignity or to recognize their humanity; it treats them as things rather than as human beings or it uses then as a means to an end rather than as ends in themselves. But these arguments can be undermined by the recognition that, unless we are pacifists, we may support measures in wartime that inevitably lead to the suffering of innocents and that we cause that suffering to achieve a larger end of winning the war. In so doing, we arguably treat those innocent victims as as a means to an end. Perhaps we justify the war by the notion of selfdefense. But then our strong condemnation of torture stands next to our defense of the idea of self-defense; one moral obligation may conflict with another and we need some way to choose between them.

The problems of defending the foundation of any moral assertion and of reconciling conflicting moral claims are problems that philosophers have wrestled with for thousands of years. They have come up with various proposed answers to these problems but none of their solutions has stopped the vague worries we have about our ability to rest assured that our moral beliefs are justified; nor has any proposed answer been so powerful that it has knocked others out of contention. If we think critically, we are easily able to undermine any moral claim or any assertion about justice that anyone can make. If the skeptics are right, then "normative reasoning" is an oxymoron: no amount of reasoning will induce us to agree on what is right, moral, or just; persuasion is either not possible or is a matter of propaganda. ${ }^{1}$ Critical thinking appears to be at odds with normativity. When we say that torture is wrong, it is not clear that we have any answer to someone who says, "that's just your opinion."

I want to argue today that this view is precisely backwards. Critical thinking does not undermine normativity; rather, it supports it. This claim on my part may appear paradoxical. After all, further critical thinking and critical argument could undermine the very claim I am making now. The methods and techniques of critique mean that we can always think up a counter-argument or unmask an unstated and unfounded assumption. When any claim is made, we can always ask

${ }^{1}$ On the problems with normative argument, see A. Leff, 'Unspeakable Ethics, Unnatural Law', Duke Law Journal (1979), 1229-1249; P. Schlag, 'Normative and Nowhere to Go', Stanford Law Review 43 (1990), 167-191; L. Seidman, This Essay is Brilliant/This Essay is Stupid: Positive and Negative Self-Reference in Constitutional Practice and Theory, UCLA Law Review 46 (1998), 501-575. 
"why"? and at some point, reasons run out. At base, we always end up somewhere, with someone making a claim. The question is how critical thinking can get us out of the circle of doubt to arrive at some confidence that moral claims and evaluations are different from mere preferences.

The answer is that the critic who questions foundations has not gone far enough. A critical thinker who argues that values have no basis other than raw preference is making certain assumptions that she has not subjected to critical thought. She is assuming, for example, that moral claims are meaningless unless they can be proven in the same way that we can prove mathematical axioms or scientific facts. She is assuming that morality, justice, and fairness are appropriately defined and established by algorithmic decision procedures rather than by contextual human judgment. She is assuming that proof of value statements is meaningless unless it rests on premises that cannot be doubted. She is assuming, in short, that the reasoning process that is appropriate for determining mathematical truths and empirical facts is also appropriate for moral reasoning.

But a little critical thinking will reveal that nothing could be further from the truth. Think about an ordinary human decision - let's say, the decision to get married. How do people decide this question? We might say, "What is there is to talk about? One thinks about it and decides; one either prefers to get married or not; there is no right answer. It's no different than choosing which wine to have with dinner." Well, perhaps. But ordinary people do not, in general, make such a momentous decision in such a cavalier manner. They usually consider carefully, not just by determining what they feel like for the moment, but by taking the decision to be an important one about the shape of their life to come. How do we make such decisions?

We might do it this way. We might make a list of pros and cons. Then, in a fit of math envy, we might put numerical values on each of the items in the list perhaps even using dollars or Euros or whatever currency one understands to express the strength of the particular considerations on the list. Of course, choosing a numerical valuation is an inexact business but, we may think we have no choice if we are going to make the decision in a rational manner. After writing numbers for each item, we might be so excited that we cannot stand it. We might, for example, call our best friend and say something like this. "I'm deciding whether to get married. I've listed all the pros and cons and given them numerical values - don't ask how, I've done the best I can. I'm so nervous; I need to add up the numbers but it's such a momentous thing, I'm wondering if you could come over and do the math for me. Just add up the numbers and tell me how it comes out. Am I getting married or not?"

Now I think that anyone who made the decision to get married this way would be suffering from some sort of psychological impairment. He certainly appears to lack what we might call emotional intelligence. More importantly for 
our purposes, his reasoning process appears to be inappropriate to the type of decision to be made. There is nothing wrong with listing pros and cons and determining their relative importance, cogency, and weight. But a mature judgment about such a decision requires something more than the techniques we use to solve a math puzzle. The considerations on the list are likely to include things such as whether you could live with the other person day to day, how interesting the other person is, how you feel when you are together, whether you have interests in common, how the two of you relate to one another, how you handle and resolve conflicts, how you communicate, what each of you thinks about the future. Reducing each of these considerations to a numerical value distorts their meaning. Making such a decision by adding the numbers fails to see this as a human decision rather than as a math problem.

In a famous passage near the beginning of the Nichomachean Ethics, Aristotle explains that we cannot expect exactitude in the realm of moral reasoning; the nature of the subject prevents it. He explains that "[o]ur discussion will be adequate if it has as much clarity as the subject-matter allows..." ${ }^{2}$ We need to give up our expectation that normative argument should derive the answers to hard questions from uncontroversial premises as well as our expectation that we need decision procedures that generate answers in a mechanical or deductive fashion. ${ }^{3}$ What we do need are structures of normative reasoning that recognize the inevitability of controversial normative premises and procedures, but also the need for contextualized human judgment to apply those normative methods to concrete cases. ${ }^{4}$

${ }^{2}$ Aristotle, Nichomachean Ethics (New York: Dutton, John Warrington ed. 1963), at 5.

${ }^{3}$ As Isaiah Berlin argued in a radio address in 1957:

The arts of life-not least of politics—as well as some among the human studies turn out to possess their own special methods and techniques, their own criteria of success and failure... Bad judgment here consists not in failing to apply the methods of natural science, but, on the contrary, in over-applying them... To be rational in any sphere, to apply good judgement in it, is to apply those methods which have turned out to work best in it... [To demand anything else] is mere irrationalism.

Isaiah Berlin, quoted in S. Toulmin, Return to Reason (Cambridge, Massachusetts: Harvard University Press, 2001), at viii.

${ }^{4}$ See R. Fogelin, Walking the Tightrope of Reason: The Precarious Life of a Rational Animal (Oxford; New York: Oxford University Press, 2003), at 61-62 ("It is essential to see that an irreconcilable moral conflict can exist without bringing all morality down around it.... Thinking otherwise is almost certainly the result of placing ultrarationalist demands on moral systems. They are either dilemma-free or wholly arbitrary. A leading aim of this work is to break the spell of thinking of that kind."); W. Kymlicka, Contemporary Political Philosophy: An Introduction (Oxford; New York: Oxford University Press, 2nd ed. 2002), at 44-45 ("What we have in political 
Of course, if we subject this insight to critical thinking, we can foresee a problem. If we cannot expect exactitude in the areas of morality and justice, then we have no assurance that our value claims are anything other than rationalizations for power relationships. I want to confront this major concern head on by admitting that it is true. We have no iron-clad way to prove a claim of justice or morality. The question is whether this fact somehow makes such claims self-serving, meaningless or distorting. The answer is no; the truth is that normative claims do not require indubitable foundations. Indeed, critical thinking is what reveals the dangers of belief in secure foundations. It is those who are certain that they are right who fail to engage in appropriate moral reasoning. Over-confidence in one's moral claims leads to tyranny.

To quote the great anthropologist Clifford Geertz, "[w]e are being offered a choice of worries." ${ }^{5}$ Anti-relativists worry about becoming unmoored and having no attachment to fundamental values and they fear that this will lead to social disorder. Their opponents (whom Geertz called "anti anti-relativists") worry instead that we will be so attached to our intuitions and presuppositions that we will be unable to step back to criticize them or to appreciate how other people may think and live differently. Geertz thought the latter problem far greater than the former. I agree. Those who believe in firm foundations for their beliefs are more likely to exhibit confidence amounting to recklessness; if you want an example, just look at the Bush Administration's justifications for actions that the rest of the world conceives as torture. If we have too much faith in our own powers of reason, we can convince ourselves that almost anything we want to do is justified. Superstition will lead us astray but it is also possible to be "bewitched by reason." Because we can use reason to justify our actions, "villainy wears many masks, none so dangerous as the mask of virtue." ${ }^{6}$ Those who engage in critical thinking are likely to worry about the legitimacy of their actions yet it is not likely that they will wind up believing in nothing or feeling free to conclude that any actions are justified.

This is not to say that the critical view does not have dangers of its own. The first danger of critical thinking is that understanding that all claims can be undermined may lead us to disengage from the world, to view it as an observer rather than as a participant. Such a detached observer may understand all claims

argument is not a single premises and then competing deductions, but rather a single concept and then competing conceptions or interpretations of it. Each theory of justice is not deduced from the ideal of equality, but rather aspires to it, and each theory can be judged by how well it succeeds in that aspiration."); C.Taylor, Sources of the Self: The Making of Modern Identity (Cambridge, Massachusetts: Harvard University Press, 1989), at 7 (arguing that modernity has inherited "a deeply wrong model of practical reasoning, one based on an illegitimate extrapolation from reasoning in natural science.").

${ }^{5}$ C. Geertz, 'Anti Anti-Relativism', Am. Anthropologist 86/2 (1984), 263-278, at 265.

${ }^{6}$ These lines are from Tim Burton's movie Sleepy Hollow (Paramount Pictures, 1999). 
of morality and justice as self-serving justifications of power. It is true that strong evaluations back up exercises of force; indeed, they are part of what makes the use of force possible. But this does not justify a stance of disengagement. Critical thinkers who see all value claims as nothing more than assertions of power seek to exhibit a certain form of sophistication-they hope to avoid naïveté by recognizing that evaluative assertions represent power moves. While it is important to remind ourselves that moral claims are indeed claims made by some people on others, an attitude of disengagement represents false sophistication. Such an attitude pretends that we can live without a moral compass. But human beings cannot live in such a disengaged world - at least if they want to remain human. As Charles Taylor explains:

[T]o be a full human agent, to be a person or a self in the ordinary meaning, is to exist in a space defined by distinctions of worth. A self is a being for whom certain questions of categoric value have arisen, and received at least partial answers. Perhaps these have been given authoritatively by the culture more than they have been elaborated in the deliberation of the person concerned, but they are his in the sense that they are incorporated into his self-understanding, in some degree and fashion. My claim is that this is not just a contingent fact about human agents, but is essential to what we would understand and recognize as full, normal human agency. ${ }^{7}$

A second danger with the critical stance is that we may refuse to judge the claims of others, not because we try to live outside a moral universe, but because we believe that it is wrong to impose our views on others. This view suggests that we cannot argue that anyone else is wrong; it assumes that everyone is entitled to his or her own opinion. After all, if the statement that "torture is wrong" means anything more than "I prefer that you stop torturing that man," then we are attempting to impose our moral beliefs on others. In doing so, we are arguably failing to respect the autonomy of others. By imposing our beliefs on other people, we fail to treat them as equally important to ourselves. Worse still, normative justifications offered by judges in a judicial opinion may even be insulting to the loser. They suggest that anyone who was thinking properly would agree with the result being reached and identify it with truth and justice. If this is so, then one who disagrees is foolish, or stupid, or selfish. Johan van der Walt argues that judicial claims to do justice amount to hubris; someone loses and the judge says it is all for the best (van der Walt, 2006). Pangloss would be proud. According to van der Walt, justice inevitably involves sacrifice. Telling the loser that her interests are illegitimate arguably denies her humanity; it fails to treat her with equal concern and respect. We can only approximate justice if judges do not

\footnotetext{
${ }^{7}$ C. Taylor, Philosophy and the Human Sciences: Philosophical Papers 2 (Cambridge; New York: Cambridge University Press, 1985), at 3.
} 
paper over the inevitable sacrifices of individual interests that are required when we adjudicate disputes one way or the other. If we do this - if we openly acknowledge the sacrifices of the losing party - then all normative claims are put in doubt.

While it is correct to claim that it is problematic to impose our views on others, it is equally problematic to contend that moral assertions inevitably deny the equal autonomy of others. Indeed, I would argue that the contrary is often true. To defer to the views of others, regardless of their content, is to treat others like children. Grownups are responsible for their actions; when they affect others, they should be able to justify themselves by reasons that others can accept. To assume that we have the right to act without justifying ourselves is to assume that we have the right to act as we please, regardless of the effects of our actions on others.

But we know that this is not true. The basis of morality is the demand to give reasons that could or should be accepted by others. In one of the founding Western myths, morality began when God approached Cain after he killed his brother Abel. God asked Cain a simple question: meh asitah, what have you done? The call to justify yourself to others is based on the idea that we do not live alone and that other human beings are as important as we are. It is right to worry about imposing your views on others; that, after all, is what was wrong with imperialism and fascism, and it is what was wrong with Cain's murder of Abel. But it is equally wrong to believe that the way to show respect to others is to defer to their beliefs, no matter what they happen to be. We treat others with equal concern and respect by taking their views seriously and we do that by subjecting their views to critical analysis. But we treat ourselves seriously as moral agents only if we subject our own moral demands to similarly searching inquiry.

Deference to others, no matter what they think, is an interpretation of what it means to treat others with equal concern and respect, but it is a faulty interpretation of that moral value. It assumes that we are free to indulge in any preferences we like and that it is no one's business but that of ourselves what we choose to believe. But this again is false. The assertion of a preference is not a self-regarding act. While it may be true that holding a preference may be a selfregarding act, asserting it against another and demanding that others defer to one's preferences is anything but a self-regarding act. And actions that affect others require justification.

In a revealing passage, Johan van der Walt explains that responsibility requires both a sense of empowerment and a sense of humility. "The notion of responding to a responsibility," van der Walt argues, "confronts us with a paradox. It clearly involves an element of choice and a complete absence of choice. Responding to a responsibility to which one is called upon to respond is not the act of a subject. But neither is it simply a matter of being 'subject to' a 
responsibility. To be responsible is a mode of existence that cannot be reduced to either the passive or the active voice." ${ }^{8}$ This is a brilliant elaboration of the stance required by critical normativity. We are in a position of responsibility that requires us to make choices about right and wrong. We are not free to retreat and to leave such matters to others. Nor are we free to pretend that we can live without such choices. Yet at the same time, we do not make those choices in a vacuum; we make them embedded in a particular set of cultures and perspectives, a complex historical setting, and within social relationships mediated by our moral traditions.

Values are different from preferences because they entail claims we make on each other. Critical normativity requires acknowledgment that human beings cannot live without such claims but that we are obligated to be careful about them. What we need is an attitude of restraint and caution combined with a fierce belief in justice. How do we adopt such a paradoxical stance? How do we view two sides of the coin at the same time? One might think that our physical embodiment in three dimensions prevents us from being in two places at once or seeing two sides of the coin; but the truth is that we have resources for escaping the limitations of our understanding. Indeed, we can learn that it is possible to live with contradictions by reminding ourselves that we do it all the time. Human beings, it seems, are fourth dimensional creatures living in a three-dimensional world. We are limited by our contexts but we have the resources to escape and shape them. We are, to paraphrase my friend Marcel Pallais, "the builder[s] of an historical edifice: the [human] House. [We are] the brick and the firm foundation of [our] own project and also the goal for whom the House is being constructed." ${ }^{9}$ We are "the player and the cards." ${ }^{10}$ The best way to understand this paradoxical stance is through stories that reveal the tensions that are at the heart of the human predicament. Here, then, are three parables of justice.

First parable: There is a village in France called Le Chambon-sur-Lignon and a great miracle happened there. ${ }^{11}$ At incredible risk to themselves and their families, the villagers saved thousands of Jews from death at the hands of the Nazis. Most of the people they saved were children. The town of Le Chambon

${ }^{8}$ J. van der Walt, The Twilight of Legal Subjectivity: Towards a Deconstructive Republican Theory of Law (Doctor of Laws Thesis, Rand Afrikaans University, 1995)(on file at Langdell Library, Harvard Law School), at 431.

${ }^{9}$ Marcel Pallais-Checa, Sketches on Hegel's Science (1977)(unpublished thesis on file at Sawyer Library at Williams College, Williamstown, Massachusetts, USA), at iv.

${ }^{10}$ Ibid.

${ }^{11}$ This account is based on the book by Philip Hallie, see Philip Hallie, Lest Innocent Blood Be Shed: The Story of the Village of Le Chambon and How Goodness Happened There (New York: HarperPerennial, 1994), and the documentary film by Pierre Sauvage, Weapons of the Spirit (Le Chambon Foundation, 1989). 
was in the unoccupied zone of France, an area run by a French government that generally followed the dictates of the German occupiers in the north. When Jews appeared at the front doors of the homes in the town and asked for shelter, the townspeople gave it to them. One of the first to do so was Magda Trocmé, the Italian wife of the village pastor, a pacifist by the name of André Trocmé. A simple thing, to invite someone into your house - but of course, not so simple, when the someone is a stranger, when she is a member of a despised group, when she is being hunted down by men with guns, men who come in armies and who see those strangers as less than human, as unfit to live, and when those men are ruthless and insistent on hunting down the outcasts and killing them and all those who help them. Not so simple. And yet, the villagers invited in the Jews. Why?

Several people have tried hard to answer this question. Philip Hallie wrote a book about the village, Lest Innocent Blood Be Shed, and Pierre Sauvage produced a documentary movie about Le Chambon-sur-Lignon called Weapons of the Spirit. Both sought to find out why the town saved so many people. Sauvage himself was born in Le Chambon during the war and wanted to know why these particular townspeople saved his parents and made his life possible. What did Hallie and Sauvage find out?

When the villagers were asked why they did this amazing thing, they were embarrassed; they were even annoyed. They not think they were heroes. They did not feel as if they had done something extraordinary. They did what had to be done; indeed, many did not even feel they had a choice. Madame Eyraud, one of the villagers, could not understand the question when she was asked why she exposed herself and her family to danger by inviting the refugees into her house. "Look, look," she said. "Who else would have taken care of them if we didn't? They needed our help, and they needed it then." ${ }^{12}$ In effect, the villagers said, "There they were, terrified, in dire straits, at our doors. What were we supposed to do? Turn them away?" Well, yes, most of us might say, you could have turned them away; indeed, most people faced with this situation did just that. And after all, you had your own families to think about. It would have been perfectly understandable to say no. But that would not have been possible for the people in Le Chambon. Why not?

For one thing, they were Huguenots - Protestants in a Catholic country. And the crucial thing is that they remembered being oppressed. Like Jews who celebrate the festival of Pesach (Passover) by telling the story of our liberation from slavery, the villagers told the story of their own exile. When they looked into the eyes of these Jews, these outcasts, these despised minorities, they saw themselves. André Trocmé, their ebullient and charismatic pastor, had himself been a refugee in World War I. He had been homeless and starving. He knew what it was to be an outcast, to be a stranger in a strange land. And in his

\footnotetext{
${ }^{12}$ Hallie, ibid. at 127.
} 
sermons, he reminded his parishioners about the sufferings of the French Protestants at the hands of intolerant Catholics. The townspeople remembered how they had been oppressed; they remembered how they wished others had helped them, and here was a chance to do what should have been done for them. The stories we tell ourselves matter because they shape the kinds of people we become.

For another thing, the villagers had read their Bible. "You know the heart of the stranger," reads the text of Leviticus, "for you were strangers in the land of Egypt." They had read the story of how Abraham and Sarah rushed to greet three strangers approaching their tent in the heat of the dessert and how they rushed to feed them and give them water and bring them into the cool of the tent. They read about Lot who refused to turn the strangers in his house over to the crowd in Sodom that wanted to attack and rape them. Why did the people of this small town in France take in these outcasts? They had read in the book of Deutoronomy, chapter 19, verses 7 to 10, about God's commandment to establish cities of refuge "lest innocent blood be shed in your land." Trocmé taught them that "turning somebody away from one's door is not simply a refusal to help; it is an act of harmdoing." ${ }^{13}$ He taught them that when strangers in dire straits come to your gate, you should let them in. And so they did. This explanation of their actions is majestic in its simplicity and stunning in its humility. The image it evokes is arresting: a human being in need standing before you.

The sense of responsibility evoked by this image requires the willingness to see the other person, as well as an ability to see that person as human. It is not a foregone conclusion that we will see others or, if we do see them, that we will recognize them as human beings like ourselves. The great legal realist Felix Cohen began an essay on United States injustices against American Indians by telling the following story:

A certain rich man was enjoying a banquet. As he sat at the groaning table he could see outside the window, at the door of his home, an old woman, half starved, weeping. His heart was touched with pity. He called a servant to him and said: "That old woman out there is breaking my heart. Go out and chase her away." ${ }^{14}$

There is a movie my family likes called Ever After, which stars Drew Barrymore and Angelica Huston. It is a version of the Cinderella story. The first time the prince meets the Cinderella character, a woman named Danielle, he is busily taking one of her family's horses. The prince's face is covered and Danielle does not recognize that he is the prince so she pelts him with apples to

\footnotetext{
${ }^{13}$ Ibid. at 124.

${ }^{14}$ Felix S. Cohen, 'Indian Claims, in The Legal Conscience: Selected Papers of Felix S. Cohen' (New Haven: Yale University Press, Lucy Kramer Cohen ed. 1960), at 264.
} 
stop him from stealing the horse. He uncovers his face and sees her - she is a servant. The second time they meet she is dressed as a courtier in a fancy gown; she goes to court to buy a servant her stepmother has sold into slavery to pay the stepmother's debts. The prince does not recognize her even though he has met her before; she looks somewhat familiar but because she is wearing a fancy dress, he does not connect her to the servant he met before. The third time they meet, she is dressed again as a servant. She is alone, swimming in the river. Who will the prince see? Will he see the servant or the courtier? All the evidence points to her being a servant. She is dressed in servant's clothing and she is alone; she is not surrounded by servants of her own. Yet the prince sees her as the courtier. My daughter Mira explains why. "He did not see the servant because he did not see the servant." When the prince first met her, he did not really look at her; he did not see servants as equals, as people to whom he should pay regard. He did not see her as a human being at all.

The people of Le Chambon saw the Jews at their gate and they saw them as human beings. When the French authorities demanded that the villagers turn over the Jews staying in the town, and argued that this was required as a matter of national harmony, they refused. Pastor Trocmé said, "It cannot be a matter of national harmony when our brothers are threatened with deportation." The local prefect Robert Bach replied that "foreign Jews ... are not your brothers" and you must hand them over to us. Trocmé replied, "We do not know what a Jew is. We know only men." ${ }^{15}$

Second parable: In the Jewish tradition, morality is founded in a covenant with God, a covenant entered into at the foot of Mount Sinai. There are many stories about why God gave the Jews the Torah. ${ }^{16}$ In one version, God offered the Torah to every nation on earth and they all refused. The demands of living within the bounds of morality and justice were too great. We were the last ones to be asked and we alone said yes. ${ }^{17}$ Now obviously, we could read this story in a as extremely self-congratulatory; we can be credited with accepting the responsibilities and limitations of a moral life. But, of course, the story can also be read in a more self-critical manner; after all, it may reflect an inclination to defer to a higher power - rather than an acceptance of responsibility, it may represent deference to authority. This latter interpretation is supported by a second version of the story which holds that, like all the other nations of the world, we were extremely reluctant to accept the Torah. But God convinced us by picking up Mount Sinai and holding it over our heads. We looked up and saw

\footnotetext{
${ }^{15}$ Hallie, supra n. 13, at 103.

${ }^{16}$ See Louis Ginzberg, Legends of the Jews, Volume 3: Moses in the Wilderness (trans. Paul Radin)(Baltimore: Johns Hopkins University Press, 1998), at 85-94.

${ }^{17}$ Ibid. at 86-88.
} 
that God was about to drop a mountain on us if we did not accept the obligations of a covenant with God. Naturally, we agreed. ${ }^{18}$ In effect, this story also holds that we were chosen by God, not because we were better than others, but because we were the last ones on the list; like being the last child called in class just because your name starts with a Z .

Yet a third version of the story portrays the origins of morality in another light. It is this version that reflects the demands of critical normativity. In this version, when God offered the Jews the Torah, the world went completely silent; no bird sang, the sea did not roar, no creature uttered a sound. ${ }^{19}$ In effect, the world disappeared. Avivah Zornberg explains that, at that moment, we looked down and saw nothing; beneath our feet there was an abyss - no ground to stand on. The great Jewish commentator Rashi tells us that, when God created the world, creation was suspended on the sixth day. Creation itself was conditioned on our accepting the Torah at Mount Sinai. If we did not accept the Torah, the world could not be sustained. All creation depended on the Jews saying yes. According to Rashi, the ground would exist for human beings to stand on only if we recognized our own responsibility to complete the creation of the world, only if we saw and understood, that morality rested on us and us alone.

Looking down and seeing an abyss; looking up and seeing God. And in between, we have ourselves. We must be the ground we stand on. Not every ground will hold solid; only a proper ground can serve as a foundation for human life. We are permanently lodged between the abyss and the mountain; we need the norms of justice that the mountain represents but we also need to see the abyss that undermines the permanence and the solidity of those norms. Life is what happens in the middle where we acknowledge our responsibilities to ourselves and to each other. How do we do this? We do this, as I have explained, by seeing each other. This is more difficult than it may sound and that brings me to the third parable of justice.

Third parable. There is movie I love called Stranger than Fiction. ${ }^{20}$ The hero is a man named Harold Crick. Harold is an accountant who works for theInternal Revenue Service, the federal agency responsible for collecting federal income taxes in the U.S. He is methodical and logical and lives a supremely ordered life. He follows the same pattern every day; he is controlled and calm. Yet his life is empty and he is lonely. He is admired by his co-workers but he has no real friends and no true human connections. Then one morning after he wakes up, he hears the voice of someone who begins narrating his life, describing what he does

\footnotetext{
${ }^{18}$ Ibid. at 92.

${ }^{19}$ Ibid. at 94.

${ }^{20}$ Some quotes in this section are taken from the feature film itself or from the original screenplay, Zach Helm, Stranger than Fiction (New York: Newmarket Press, 2006).
} 
as he does it. The voice begins to follow him every day. And the coup de grâce is that, one day, as Harold is waiting for the bus, his watch stops and he needs to reset it. As he does so, he hears the narrator say, "Little did he know that this simple, seemingly innocuous act would result in his imminent death."

At that moment, predictably, Harold goes nuts. He tries to figure out who is talking to him. He consults a psychiatrist who tells him he has schizophrenia. But Harold knows more than the expert; he knows that this is not the case. He realizes, in fact, that he is a character in a novel and the voice he is hearing is the voice of the narrator. Yet, at the same time, Harold does not feel like a character in someone else's story. He is, after all, alive, and he hopes to remain so. When he insists he is the character in a novel, the psychiatrist suggests he consult a literary expert. So Harold goes to the university and finds a literature professor who takes him seriously. They begin a quest to find out who is Harold's author so that Harold can seek out the author and ask the author not to kill him.

The professor suggests that Harold determine who is in control of his story, the author or himself. Is he the author of his own life or is someone else pulling the strings? Do his actions change the shape of his story or does the author impose things on him against his will? It turns out to be a little of both. The author, it seems, is hell-bent on ending the story with Harold's death, and when Harold's apartment is attacked by a wrecking ball while he is inside watching television, the professor concludes that Harold is not in charge of his own story. But that does not mean that Harold's life is over yet. The professor tells Harold to live his life within the bounds given him. If you don't have much time left, the professor says, make it the life you want to have. Harold accepts this advice and, remarkably, his life changes in dramatic ways; he takes a vacation from work, he learns to play the guitar, he slows down, he falls in love, he learns to be a friend. Knowing he is to die soon, knowing his limits, Harold becomes liberated. He is reminded about what it means to be a human being, and this releases him from his calculations, his counting, his rigid formulae.

The professor advises Harold to live within the boundaries given to him and he does so. But eventually, Harold discovers the identity of the author and he arranges to meet her. When they do meet, he asks her not to kill him. Rather than accept the boundaries established by his author, Harold seeks to remake those boundaries. He wants to become the author of his own life. The meeting between the author and her character is, of course, incredibly strange; as the movie title says, it is stranger than fiction. Because it is impossible, it is an exact metaphor for the paradox of the human condition and for the problem posed by moral claims. How can we be bound by moral standards we ourselves create? How are normative claims possible when we are both the authors of our own lives and characters in a social world created by others?

The author meets her character and, as we expect, Harold asks her not to end his life. For her, this is a bewildering turn of events. The author, Karen Eiffel, has 
written many novels and each one ends with the death of the main character. She has been agonizing about how to kill Harold Crick; she has been suffering from acute writer's block; it has been ten years since her last novel. It is so bad that the publisher sent an assistant named Penny to live with her, to help her finish the book. And after excruciatingly painful equivocation, the author has a burst of insight and decides how Harold's life will end. And it is just at that moment that she meets her character and he asks her to save his life.

A human being, standing before you, in need. The people of Le Chambon knew what to do in such a case. But our author is in a quandary. Harold Crick is her character; she made him up; she writes novels; this is what she does; it is her signature mode to write a story of how ordinary people go about their lives not knowing that their time on earth is about to end. She has been searching for the perfect way to kill Harold Crick and finally it strikes her, like lightning, how to do it. When she figures it out, her assistant Penny asks her how she did it. "Well, Penny," the author caustically replies, "like anything worth writing, it came inexplicably and without method." "And what kind of death does the author imagine for Harold? "It's perfect actually," she says. "I can't believe I didn't think of it earlier. It's simple, ironic... possibly heartbreaking." What would a perfect death be like and why does she want to break our hearts? The author wants to break our hearts so we can discover a truth, so we can feel the paradox of the human condition, so we can remember how important human beings are. One of my professors once said that we will appreciate each day more if we have a sense of the ending, if we look at everything not as if we were seeing it for the first time, but as if we were seeing it for the last time, and would never experience it again. Harold's author is crafting the perfect death to show how precious human life is. Yet here is her character, alive, asking her to change the ending.

At this point, the final scene in her novel is written on legal pads; it only remains to be typed. What to do? "Let him read it," the assistant says. "Let him read it." The author agrees and hands Harold the manuscript. But Harold cannot bring himself to read it. Instead, he takes it to the professor and he asks the professor to read it to see if there is any way to re-write the story so as to save Harold's life. The professor reads the story and then meets Harold in his office. "I'm sorry," the professor says. "You have to die.... I'm sorry, but it's brilliant, Harold. It's... It's her masterpiece.... It's possibly the most important novel in her already stunning career. And it's absolutely no good unless you die at the end."

Harold is distraught. "I could change," he said. " I could be someone else, I could go away." No, the professor responds, the book is perfect and it does not work if you do not die. Picture the scene. The professor in his office, the character sitting before him, crying, saying that he wants to live. The professor answers that it has to be this way. The book is a masterpiece and the price of a masterpiece is Harold Crick's life. The professor then tries to justify this to Harold. Listen, the professor says, you will die sometime; all of us will. And it 
could be a meaningless death. The one she's written for you is meaningful. But, Harold argues, I am still alive; I just fell in love, I just started my life, I don't want to die. The professor cannot be moved. The pages, after all, are written on a legal pad. What the professor sees is the story; what he understands are the rules for masterpieces. What he does not see is the human being standing in front of him.

Harold takes the book and reads it all the way to the end. And when he does that, he returns it to the author and says an extraordinary thing: "I loved your book," he said. "And I think you should finish it." He says this, even though it means that he is accepting his imminent demise. Karen Eiffel, the author, is nonplussed. She begins to type the ending but, in the end, she cannot do it; she cannot bring herself to kill Harold Crick. The ending she had written tells how Harold stepped in front of a bus to save a little boy's life. Harold told her to finish the book even though he knew it meant that he would die. Perhaps he thought that the author was entitled to her story, to her vision, even though it would cost him his life. Perhaps he did it for the sake of art. But it is far more likely that he did it because he learned about the boy whose life he was supposed to save. If Harold himself was real, then perhaps the boy was real as well, and if the boy would die unless Harold saved him, then unless Harold accepted his fate, the little boy would die in his place. Harold saw the boy and this seems to be the reason he told the author to finish the book.

This made all the difference. In the end, the author changed the ending. Harold Crick does not die; the author rewrites the book and saves his life. After doing so, she meets the professor; he is an avid fan of her books and she is anxious to show him the new ending. The professor reads the new ending and says, "It's okay. It's not bad; it's not the most amazing piece of American literature in several years but... it's okay." And then the author says an amazing thing. "You know," she says, "I think I'm fine with okay." She is willing to sacrifice a masterpiece for something that is just okay.

"Why did you change it?" the professor asks her. "Because he's real?"

"No," Karen Eiffel responds. "Because it's a book about a man who doesn't know he's about to die... and then dies. But if the man does know he's going to die, and dies anyway... dies willingly, knowing he could stop it... well... isn't that the kind of man you want to keep alive?"

Unbeknownst to the author, it turns out that she has created a character who could be the embodiment of the people of Le Chambon; he is willing to sacrifice his own life to save a child. What are the author's obligations with respect to such a person? The professor thinks she should focus on the idea of perfection; the professor has a theory about great novels and what they require. He knows that human lives have meaning and that they get that meaning partly because each of us is unique and our lives are finite and incredibly precious. The author realizes this too; she agonized about the perfect death because something important was 
at stake - the creation of a meaningful life. Unlike the professor, however, the author was not trapped within a theory. She was not imprisoned by the rules of literature. Despite her protestations, she was shocked by meeting her own character and learning that he was real, that he was a human being, standing before her, asking to live. The author changes upon seeing him; she gives up the burden of creating a masterpiece, and she does so to save a human life. She gives up the comforts of certainty, the guidance of clear theory. Instead, she says "I think I'm fine with okay." She is humble about theory but ambitious about humanity.

At that moment we see the vulnerabilities of the author and the professor in sharp relief. The author has had writer's block, wanting the perfect book, the perfect meaningful death for Harold. Her book is called Death and Taxes. In the old joke, nothing is certain but death and taxes, and the author is seeking certainty; she has delayed ten years in seeking the perfect ending. According to the professor, she achieved it; the book is her masterpiece. But she gives up the chance to save a life, and the life she saves may just be her own. For years, the professor has been writing her, telling how he loves her books. She loved his letters, but she did not answer him. It turns out that she was as isolated as was her character Harold Crick before he found out he was about to die. And as she tells the professor that she's fine with okay, as she gives us the idea of the perfect ending, she looks at the professor and he looks at her, and they connect. The movie does not say anything more about their relationship, but the original screenplay has them going go out for tea together, and possibly happiness. They have things to teach each other, the author and the professor, the purveyor of narrative and the purveyor of theory. They may learn something about the meaning of human life, something that comes from breaking the rules.

This leaves us with two key insights. First, it is absolutely crucial that see people as human; that requires in turn that we see ourselves as human. When we see each other as human beings, rather than pawns on a chess board, it turns out that most of us will feel certain moral demands. Those demands not only constrain our own preferences, but they give us a sense of what we are entitled to ask of others. Seeing each other as human also takes many things off the table; it limits the kinds of reasons we can give for our actions and it limits the kinds of laws that are acceptable in a free and democratic society that aspires to treat each person with equal concern and respect.

Second, if we must choose between an airtight deductive system for reasoning about justice and a messy, contextual approach that relies on human judgment, then human beings are almost sure better off choosing the latter. To justify values, we must forego formulas and learn to live with paradox and ambiguity. This does not mean that we do not engage in critical thought; indeed, it requires us to see both sides of the coin (especially arguments and counterarguments). It especially requires us to consider how moral questions look from 
the standpoint of the loser. Reasons must be given that could or should be accepted by the loser. This task requires us, in effect, to be two places at once; we must have double vision. It turns out that time is not the fourth dimension; morality is.

In the end, we are left with considered judgment and persuasive justification through offering reasons we think others should be able to accept. Logic is part of this enterprise but it cannot substitute for experience and judgment; we reach temporary foundations when we are, for the moment, satisfied that we have done the best we can. There are no rules for determining when that occurs. ${ }^{21}$ As the author says, much that is most worth writing comes "inexplicably and without method." Perhaps, in the end, perfection in the realm of reasoning about justice and morality depends on giving up fantasies of absolute foundations and logical procedures. If we are to see the human beings in need standing before us, we must be both engaged and critical, we must be both confident and cautious, we must embrace both justice and humility. We need both human commitments and open minds. What we seek are normative claims that are strong but contestable. Such claims are not irrefutable; ye they are good enough. They are not masterpieces; they are merely okay. And you know what? I think we would be fine with okay.

JOSEPH WILLIAM SINGER

Bussey Professor of Law

Harvard Law School

Cambridge, Massachusetts 02138

USA

jsinger@law.harvard.edu

Aristotle, 1963 ed. Nichomachean Ethics, ed. John Warrington. New York: Dutton.

Cohen, Felix S. 1960. Indian Claims, in The Legal Conscience: Selected Papers of Felix S. Cohen, ed. Lucy Kramer Cohen. New Haven: Yale University Press.

Fogelin, Robert. 2003. Walking the Tightrope of Reason: The Precarious Life of a Rational Animal. Oxford; New York: Oxford University Press.

Geertz, Clifford. 1984. Anti Anti-Relativism. American Anthropologist 86:263-278.

Hallie, Philip. 1994. Lest Innocent Blood Be Shed: The Story of the Village of Le Chambon and How Goodness Happened There. New York: HarperPerennial.

\footnotetext{
${ }^{21}$ See Joseph William Singer, 'Normative Methods for Lawyers', - UCLA Law Review (forthcoming, 2009)(describing multiple normative methods for discussing and justifiying choices based on considerations of fairness and justice).
} 
Helm, Zach. 2006. Stranger than Fiction New York: Newmarket Press.

Kymlicka, Will. 2002 (2nd ed.). Contemporary Political Philosophy. Oxford; New York: Oxford University Press.

Leff, Arthur Allen. 1979. Unspeakable Ethics, Unnatural Law, Duke Law Journal 1979:1229_ 1249.

Louis Ginzberg. 1988. Legends of the Jews, Moses in the Wilderness 3:85-94, trans. Paul Radin. Baltimore: Johns Hopkins University Press.

Pallais-Checa, Marcel. 1977. Sketches on Hegel's Science. Williams College Library, Bachelor or Arts Thesis, Williamstown, Massachusetts, USA.

Sauvage, Pierre. 1989. Weapons of the Spirit. Le Chambon Foundation.

Schlag, Pierre. 1990. Normative and Nowhere to Go. Stanford Law Review 43:167-191.

Seidman, Louis Michael. 1998. This Essay is Brilliant/This Essay is Stupid: Positive and Negative Self-Reference in Constitutional Practice and Theory. UCLA Law Review 46:501575.

Singer, Joseph William. 2009. Normative Methods for Lawyers, UCLA Law Review. forthcoming, 2009.

Sleepy Hollow. 1999. Paramount Pictures.

Stranger than Fiction. 2006. Columbia Pictures.

Taylor, Charles. 1985. Philosophy and the Human Sciences: Philosophical Papers 2.

Taylor, Charles. 1989. Sources of the Self: The Making of Modern Identity. Cambridge, Massachusetts: Harvard University Press.

Toulmin, Stephen. 2001. Return to Reason. Cambridge, Massachusetts: Harvard University Press.

van der Walt, Johan 1995. The Twilight of Legal Subjectivity: Towards a Deconstructive Republican Theory of Law. Rand Afrikaans University, Doctor of Laws Thesis, on file at Langdell Library, Harvard Law School, Cambridge, Massachusetts, USA.

van der Walt, Johan 2006. Law and Sacrifice: Towards a Post-Apartheid Theory of Law.

Weapons of the Spirit. 1989. Chambon Foundation, producer, Pierre Sauvage. 